\title{
PENGGUNAAN BAKTERI Lactobacillus plantarum PADA SILASE KULIT PISANG KEPOK (Musa paradisiaca $L$ ) SEBAGAI PAKAN TERNAK
}

\author{
Use of Lactobacillus plantarum in Kepok Banana Peels Silage \\ (Musa paradisiaca L) as Livestock Feed
}

\author{
Nurkholis', Dyah Laksito Rukmi', Yuni Mariani' \\ 1 Jurusan Peternakan, Politeknik Negeri Jember \\ 2Manajemen Agroindustri, Politeknik Negeri Jember \\ Email: nur78.nk@gmail.com
}

\begin{abstract}
INTISARI
Penelitian ini bertujuan untuk mengetahui pengaruh penggunaan Lactobacillus plantarum terhadap kualitas silase kulit pisang kepok. Desain eksperimental yang digunakan pada penelitian ini adalah Rancangan Acak Lengkap (RAL) dengan 4 perlakuan dan 5 ulangan. Perlakuannya yaitu silase tanpa inokulasi L. plantarum (T1), inokulasi $10^{4} \mathrm{CFU} / \mathrm{ml}$ (T2), $10^{5} \mathrm{CFU} / \mathrm{ml}$ (T3), dan $10^{6} \mathrm{CFU} / \mathrm{ml}$ (T4). Hasil penelitian menunjukkan bahwa bahan kering silase kulit pisang kepok tidak berbeda antar perlakuan. Perlakuan inokulasi L. plantarum mampu meningkatkan $(\mathrm{P}<0,05)$ kandungan protein kasar dan lemak kasar serta menurunkan $(\mathrm{P}<0,05)$ kandungan serat kasar dan nilai pH silase. Penambahan inokulasi L. plantarum pada silase kulit pisang kepok mampu memperbaiki kualitas silase sebagai alternatif pakan ruminansia.
\end{abstract}

Kata kunci : Kulit Pisang Kepok, Lactobacillus plantarum, Silase

\section{ABSTRACT}

This study aims to determine the effect of the use of Lactobacillus plantarum on the banana kepok silage quality. The experimental design used in this study was Completely Randomized Design (CRD) using 4 treatments and 5 replications. The treatment was silage without inoculation $L$. plantarum (T1), inoculation $10^{4} \mathrm{CFU} / \mathrm{ml}$ (T2), $10^{5} \mathrm{CFU} / \mathrm{ml}$ (T3), and $10^{6} \mathrm{CFU} / \mathrm{ml}$ (T4). The results showed that the dry material of kepok banana peels silage was not different between treatments. The inoculation treatment of L. plantarum was able to increase $(P<0.05)$ of crude protein and crude fat content, but decrease $(P<0.05)$ crude fiber content and $p H$ silage. The addition of $L$. plantarum inoculation to kepok banana peels could improve the quality of silage as an alternative ruminant feed.

Keywords: Kepok Banana Peels, Lactobacillus plantarum, Silage

\section{PENDAHULUAN}

Kulit pisang kepok merupakan limbah buah yang banyak ditemukan di industri pengolahan buah pisang seperti pabrik sale pisang, pabrik keripik pisang, dan pabrik tepung pisang. Selain itu, industri yang memanfaatkan pisang kepok adalah pembuatan cuka, bir, dan puree. Pengolahan pisang tersebut menghasilkan limbah kulit pisang kepok kira-kira sepertiga dari buah pisang utuh yang belum dikupas (Marhaenanto, 2009). Kuantitas yang cukup banyak disertai dengan kandungan nutrien yang cukup baik. Menurut Sumarsih et al. (2009) kulit pisang mengandung protein kasar 7,08\%, serat kasar 8,34\%, lemak kasar 11,8\%, abu 9,66\%, dan BETN 63,1\%. 
Limbah kulit pisang kepok yang menumpuk di sentra industri pengolahan pisang mudah mengalami perubahan fisik, baik dari segi warna, rasa, dan aroma. Oleh karena itu supaya kulit pisang ini dapat diberikan sebagai pakan ternak perlu diolah dan diawetkan melalui teknologi silase.

Silase merupakan pengolahan dan pengawetan bahan pakan melalui proses fermentasi anaerob dengan bantuan bakteri asam laktat (BAL). Menurut Ratnakomala et al. (2006) BAL akan mengubah karbohidrat yang terlarut dalam air (water soluble carbohydrate) menjadi asam laktat. Asam laktat tersebut berperan dalam penurunan $\mathrm{pH}$ selama proses fermentasi berlangsung dan berperan sebagai zat pengawet yang dapat menghambat pertumbuhan mikroorganisme pembusuk.

BAL diharapkan mampu secara otomatis tumbuh dan berkembang secara alami. Tetapi untuk menghindari kegagalan fermentasi perlu dilakukan inokulasi BAL homofermentatif seperti Lactobacillus plantarum. Dijelaskan lebih lanjut oleh Ratnakomala et al. (2006) bahwa L. plantarum mempunyai kemampuan yang terbesar dalam menghambat mikroorganisme patogen pada bahan pangan dibandingkan dengan BAL lainnya.

L. plantarum membutuhkan sumber energi yang cukup untuk mempercepat terbentuknya asam laktat. Oleh karena itu, pada proses pengolahan silase kulit pisang kepok ini perlu ditambahkan sumber karbohidrat dari luar, salah satunya dengan penambahan molases. Molases merupakan hasil ikutan proses pengolahan tebu menjadi gula (Sumarsih, et al. 2009). Penelitian ini bertujuan untuk mengetahui pengaruh inokulasi L. plantarum terhadap kualitas silase kulit pisang kepok sebagai pakan ternak ruminansia.

\section{MATERI DAN METODE}

\section{Persiapan Inokulan L. plantarum}

\section{Peremajaan isolat}

Isolat yang digunakan dalam penelitian ini merupakan isolat L. plantarum yang diisolasi dari kotoran lunak. lsolat $L$. plantarum tcrsebut diremajakan terlebih dahulu ke dalam medium glukose yeast pepton (GYP) sebanyak satu atau dua ose ke dalam media GYP miring kemudian diinkubasi pada suhu $30^{\circ} \mathrm{C}$ selama 18 jam.

\section{Uji pertumbuhan populasi L. plantarum}

Uji pertumbuhan populasi L. plantarum pada media GYP cair dilakukan dengan cara menambahkan 10\% inokulum dari media GYP. Selanjutnya diinkubasi pada suhu $30^{\circ} \mathrm{C}$ di atas shaker incubator dengan kecepatan $150 \mathrm{rpm}$ selama 48 jam. Pertumbuhan isolat L. plantarum diamati berdasarkan perhitungan jumlah bakteri menggunakan model total plate count (TPC). Setiap interval 4 jam mulai jam ke-0 sampai jam ke-48, isolat diambil sebanyak $1 \mathrm{ml}$ dan dilakukan pengenceran sampai $10^{8}$. Sebanyak $0,01 \mathrm{ml}$ ditumbuhkan secara drop plate dalam media GYP. Selanjutnya diinkubasi dalam inkubator 
pada suhu $30^{\circ} \mathrm{C}$ selama 48 jam dan dihitung jumlah koloninya. Jumlah sel yang tumbuh dihitung dengan rumus:

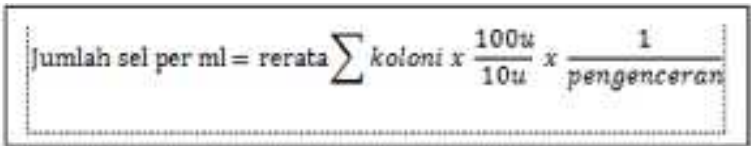

Penghitungan jumlah koloni juga disertai dengan pembuatan kurva pertumbuhan L. plantarum agar dapat ditentukan waktu pertumbuhan yang optimal dan dengan tepat menentukan jumlah populasi sel yang dibutuhkan untuk inokulan silase.

\section{Pembuatan silase kulit pisang}

Kulit pisang dibersihkan dari kotoran yang menempel kemudian dilayukan selama 48 jam untuk mengurangi kadar air yang terkandung di kulit pisang. Kulit pisang yang telah layu ditimbang sebanyak $1 \mathrm{~kg}$ untuk masing-masing perlakuan. Kulit pisang dicampur secara homogen dengan masingmasing perlakuan inokulan yang telah disiapkan. Bahan pengisi inokulan yang digunakan adalah molases. Setelah homogen, kulit pisang sesegera mungkin dimasukkan ke dalam silo plastik dan dilakukan pemadatan sampai terbentuk suasana anaerobik. Proses pemeraman dalam penelitian ini dilakukan selama 21 hari.

\section{Uji kualitas fisik dan kimia}

Silase kulit pisang setelah berumur 21 hari dibuka untuk dianalisis kualitas fisik dan kimia. Kualitas fisik silase dilakukan dengan cara mengukuran nilai warna, aroma, dan tekstur. Pengukuran nilai $\mathrm{pH}$ dilakukan sebelum dan setelah proses fermentasi menggunakan dengan cara sampel sebanyak 20 g diblender sampai halus, kemudian dilarutkan pada aquades sebanyak $20 \mathrm{ml}$ dan hasilnya dihomogenkan menggunakan shaker selama 15 menit. Setelah itu, supernatan silase disaring dan diukur menggunakan $\mathrm{pH}$ meter. Warna, aroma, dan tekstur silase dinilai oleh 10 panelis tidak terlatih. Warna, aroma, dan tekstur dinilai berdasarkan skoring menurut Andi (2006) seperti yang disajikan pada Tabel 1 .

Tabel 1. Kriteria dan Skor Penilaian Kualitas Sensoris Silase

\begin{tabular}{lc}
\hline \multicolumn{1}{c}{ Kriteria Silase } & Skor \\
\hline Warna & $(1-3)$ \\
Coklat kekuningan & 1 \\
Coklat gelap & 2 \\
Coklat hitam & 3 \\
Bau & $(1-3)$ \\
Asam & 1 \\
Tidak asam atau tidak busuk & 2 \\
Busuk & 3 \\
Tekstur & $(1-3)$ \\
Padat & 1 \\
Agak lunak & 2 \\
Lunak & 3 \\
\hline
\end{tabular}


Kualitas kimia silase kulit pisang diukur melalui kandungan nutrien di dalamnya yang meliputi bahan kering, protein, lemak, dan serat kasar. Sampel silase kulit pisang dikeringkan menggunakan oven dengan suhu 60 sampai $70^{\circ} \mathrm{C}$ selama 3 hari kemudian digiling dengan ukuran partikel $2 \mathrm{~mm}$. Sampel yang telah digiling dianalisis bahan keringnya melalui penghitungan selisih kadar air bahan dengan menggunakan oven pada suhu $105^{\circ} \mathrm{C}$ selama 1 jam. Pengukuran kandungan protein dilakukan melalui metode Kjeldahl, kandungan lemak melalui metode Soxhlet, dan kandungan serat kasar berdasarkan AOAC (2005).

\section{Rancangan Penelitian}

Penelitian dilakukan dengan metode percobaan yang berpola pada Rancangan Acak Lengkap (RAL). Penelitian ini dilakukan dengan 4 perlakuan dan 5 kali ulangan. Adapun perlakuannya adalah:

$\mathrm{P} 1=$ Kulit pisang kepok $+6 \%$ molases

$\mathrm{P} 2=$ Kulit pisang kepok $+6 \%$ molases $+10^{4}$ $\mathrm{CFU} / \mathrm{ml}$ bakteri L. plantarum

P3 $=$ Kulit pisang kepok $+6 \%$ molases $+10^{6}$ CFU $/ \mathrm{ml}$ bakteri L. plantarum

$\mathrm{P} 4=$ Kulit pisang kepok $+6 \%$ molases $+10^{8}$ CFU $/ \mathrm{ml}$ bakteri L.plantarum

Rumus Umum Rancangan Acak Lengkap (RAL)

$$
Y_{i j}=\mu+T+E i j
$$

\section{Keterangan}

$\mathrm{Y}_{\mathrm{ij}}=$ Hasil pengamatan akibat perlakuan ke-i pada ulangan ke-j

$\mu=$ Rata- rata umum

$\mathrm{T}=$ Pengaruh taraf perlakuan
Eij = Galat taraf perlakuan ke-i pada ulangan ke-j

Pada akhir percobaan dilakukan analisis dengan menggunakan rumus metode RAL dengan perhitungan ANOVA, jika hasil perhitungan keragaman dari setiap parameter memperlihatkan perbedaan yang nyata atau sangat nyata, maka pengujian akan dilanjutkan dengan uji BNT. Pengamatan uji kualitas fisik silase yang meliputi warna, bau, dan tekstur diuji secara deskriptif.

\section{HASIL DAN PEMBAHASAN}

\section{Kualitas Fisik}

\section{Warna}

Silase kulit pisang kepok yang dihasilkan mempunyai kualitas yang baik yaitu berwarna coklat. Proses perubahan warna tersebut terjadi karena mengalami proses ensilase yang disebabkan oleh perubahan-perubahan yang terjadi selama proses respirasi aerobik yang berlangsung selama persediaan oksigen masih ada, sampai gula tanaman habis. Gula akan teroksidasi menjadi $\mathrm{CO}_{2}$ dan air, dan terjadi panas hingga temperatur naik. Bila temperatur tak dapat terkendali, silase akan berwarna coklat tua sampai hitam (Andi, 2006).

\section{Bau}

Silase kulit pisang kepok mempunyai kualitas baik dengan berbau asam segar pada semua perlakuan. Bau asam yang dihasilkan oleh silase berasal dari asam yang dihasilkan selama ensilase. Hal ini sesuai dengan 
Sumarsih et al. (2009) yang menyatakan bahwa asam tersebut adalah asam laktat yang dihasilkan oleh bakteri asam laktat selama ensilase.

\section{Tekstur}

Silase yang dihasilkan agak lunak pada semua perlakuan, hal ini disebabkan karena kadar air silase kulit pisang kepok yang dihasilkan terlalu tinggi, yaitu 90,04 sampai 90,72\%. Kondisi silase ini dinilai kurang baik, karena secara tekstur terlalu lunak. Menurut Andi (2006) bahwa secara umum silase yang baik mempunyai ciri-ciri yaitu tekstur masih jelas seperti aslinya.

\section{Kandungan bahan kering (BK)}

Hasil BK silase pisang kepok tidak berbeda nyata dari setiap perlakuan. Hal ini disebabkan oleh adanya pelayuan sampai 48 jam pada semua perlakuan sebelum ensilase. Pelayuan menyebabkan berkurangnya kadar air pada bahan sehingga air yang keluar dari kulit pisang kepok selama ensilase menjadi lebih sedikit. Menurut Wulandari (2004) perlakuan pelayuan bahan sebelum pembuatan silase akan mengurangi kadar air silase yang dihasilkan.

\section{Kandungan protein kasar (PK)}

Hasil PK silase kepok pisang menunjukkan peningkatan yang nyata $(\mathrm{P}<0,05)$. Peningkatan kandungan $\mathrm{PK}$ ini diduga karena adanya kontribusi dari protein mikrobia khususnya BAL, seperti $L$. plantarum. Hal ini sesuai dengan pendapat Sumarsih et al. (2009) yang menyatakan bahwa peningkatan kandungan PK selama proses fermentasi silase terbentuk sel mikrobia.

Protein mikrobia pada pengawetan hijauan pakan secara fermentasi tersusun dari penggabungan antara nitrogen bebas dari bakteri dan senyawa sisa asam lemak volatil (campuran asam asetat, asam propionat, dan asam butirat) yang telah kehilangan ion oksigen, nitrogen, dan hidrogen. Terbebasnya oksigen, nitrogen, dan hidrogen disebabkan oleh adanya peningkatan suhu selama proses fermentasi yaitu pada saat terjadinya perombakan karbohidrat dan respirasi mikrobia dalam silo (Sumarsih et al., 2009)

Tabel 1. Rataan Kandungan Nutrien dan pH Silases Kulit Pisang Kepok Setelah Difermentasi Selama 21 Hari

\begin{tabular}{ccccc}
\hline \multirow{2}{*}{ Parameter } & \multicolumn{3}{c}{ Perlakuan } \\
\cline { 2 - 5 } & P1 & P2 & P3 & P4 \\
\hline BK & 9,96 & 9,64 & 9,46 & 9,26 \\
PK & $10,43^{\mathrm{c}}$ & $10,68^{\mathrm{bc}}$ & $11,04^{\mathrm{b}}$ & $12,14^{\mathrm{a}}$ \\
LK & $8,94^{\mathrm{a}}$ & $9,28^{\mathrm{a}}$ & $9,41^{\mathrm{ab}}$ & $9,72^{\mathrm{b}}$ \\
SK & $6,53^{\mathrm{a}}$ & $6,00^{\mathrm{b}}$ & $5,69^{\mathrm{c}}$ & $4,45^{\mathrm{d}}$ \\
pH & $4,92^{\mathrm{a}}$ & $4,74^{\mathrm{b}}$ & $4,66^{\mathrm{b}}$ & $3,65^{\mathrm{c}}$ \\
\hline
\end{tabular}

Superskrip yang berbeda pada baris yang sama menunjukkan perbedaan yang nyata $(\mathrm{P}<0,05)$ ns : non significant 


\section{Kandungan lemak kasar (LK)}

Hasil LK silase kepok pisang menunjukkan peningkatan yang nyata $(\mathrm{P}<0,05)$. Semakin tinggi konsentrasi inokulasi L. plantarum maka semakin tinggi pula kandungan LK silase kulit pisang kepok. Peningkatan kandungan LK silase kulit pisang kepok karena adanya aktivitas L. plantarum selama proses fermentasi. Hal ini sejalan dengan pendapat Isfar (2007) yang menyatakan bahwa bakteri asam laktat juga memproduksi metabolis sekunder seperti asam lemak.

\section{Kandungan serat kasar (SK)}

Hasil SK silase kepok pisang menunjukkan penurunan yang nyata $(\mathrm{P}<0,05)$. Semakin rendah kandungan serat kasar silase kulit pisang, semakin baik pula kualitas silase kulit pisang kepok yang dihasilkan. Terjadinya penurunan kandungan SK silase kulit pisang kepok diduga erat kaitannya dengan aktivitas bakteri L. plantarum. Menurut Sandi et al. (2006) penggunaan BAL (L. plantarum) pada umbi singkong mampu menurunkan serat kasar selama fermentasi. Penggunaan inokulum bakteri akan semakin mempercepat proses fermentasi dan semakin banyak substrat yang didegradasi.

\section{Nilai pH}

Hasil nilai pH silase kepok pisang menunjukkan penurunan yang nyata $(\mathrm{P}<0,05)$. Nilai pH akhir silase kulit pisang kepok disajikan pada Tabel 4. Nilai $\mathrm{pH}$ yang berbeda pada masing-masing perlakuan terkait dengan konsentrasi L. plantarum yang diinokulasikan. Nilai pH akhir merupakan salah satu tolok ukur yang penting dalam pengukuran kualitas silase, terutama kaitannya dengan daya simpan silase yang dihasilkan. Menurut Wulandari (2004) rendahnya pH sangat penting untuk mencapai kestabilan silase. Semakin rendah $\mathrm{pH}$ semakin banyak asam laktat dan asam lemak volatil yang terbentuk. Semakin tinggi kandungan asam laktat, akan mempercepat penurunan $\mathrm{pH}$, sehingga perkembangan mikrobia yang tidak diinginkan dapat dihambat, pada akhirnya dapat meningkatkan kualitas silase dan daya simpan silase. Andi (2006) mengkategorikan kualitas silase berdasarkan pH-nya yaitu: 3,5 sampai 4,2 baik sekali; 4,2 sampai 4,5 baik; 4,5 sampai 4,8 sedang; dan lebih dari 4,8 adalah jelek. Kategori tersebut didasarkan pada silase yang dibuat dengan menggunakan bahan pengawet. Sehingga perlakuan P4 menghasilkan $\mathrm{pH}$ terbaik diantara perlakuan, yaitu 3,65.

\section{KESIMPULAN}

Hasil penelitian menunjukkan bahwa bahan kering silase kulit pisang kepok tidak berbeda antar perlakuan. Perlakuan inokulasi L. plantarum mampu meningkatkan $(\mathrm{P}<0,05)$ kandungan protein kasar dan lemak kasar serta menurunkan $(\mathrm{P}<0,05)$ kandungan serat kasar dan nilai pH silase. Penambahan inokulasi L. plantarum pada silase kulit pisang kepok mampu memperbaiki kualitas silase sebagai alternatif pakan ruminansia. 


\section{DAFTAR PUSTAKA}

Andi, N.S. 2006. Karakteristik dan Persentase Keberhasilan Silase Rumput Gajah pada Berbagai Umur Pemotongan. Fakultas Pertania. Universitas Lambung Mangkurat. Banjarbaru.

AOAC. 2005. Official Methods of Analysis of AOAC International. AOAC International. Maryland.

Isfar, A.S.A. 2007. Studi Hispatologi Organ Hati Broiler yang Diberi Pakan Silase dan Ditantang Salmonella typhimurium. Fakultas Kedokteran Hewan. Skripsi. Institut Pertanian Bogor. Bogor.

Marhaenanto, E.M. 2009. Pemanfaatan Limbah Pisang sebagai Strategi Pengembangan Ternak Kambing. Fakultas Pertanian. Skripsi. Universitas Lambung Mangkurat. Banjarbaru.

Ratnakomala, S., R. Ridwan, G. Kartina, dan Y. Widyastuti. 2006. Pengaruh Inokulum Lactobacillus plantarum 1A-2 dan 1BL-2 terhadap Kualitas Silase Rumput Gajah (Pennisetum purpurium). Pusat Penelitian Bioteknologi. Lembaga Ilmu Pengetahuan Indonesia. Jakarta.

Sandi, S., E.B. Laconib, A. Sudarman, K.G. Wiryawan, dan D. Mangundjaja. 2006. Kualitas Nutrisi Silase Berbahan Baku Singkong yang Diberi Enzim Cairan Rumen Sapi dan Leuconostoc mesenteroides. Institut Pertanian Bogor. Bogor.

Sumarsih, S. C.I. Sutrisno, dan B. Sulistiyanto. 2009. Kajian Penambahan Tetes sebagai Aditif terhadap Kualitas Sensoris dan Nutrisi Silase Kulit Pisang. Pada Seminar Nasional Kebangkitan Peternakan. Fakultas Peternakan, Universitas Diponegoro. Semarang.

Wulandari, S. 2004. Evaluasi Silase Hijauan Makanan Ternak dengan Penambahan Bakteri Asam Laktat Lactobacillus plantarum dan Perlakuan Pelayuan. Seminar Nasional Hasil Penelitian Dasar Tahun 2003. Jakarta. 